\title{
BIOACTIVITY OF CINNAMON (Cinamomum sp)
}

\author{
*Department of Agricultural Technology, Faculty of Agricultural, Jambi University, \\ Jl. Tri Brata KM 11, Pondok Meja, Mestong, Muaro Jambi 36364, Indonesia \\ E-mail: fitrytafzi@unja.ac.id
}

\begin{abstract}
Cinnamon has been widely used as a spice in food and medicine. Cinnamon grow in the Asian region. Indonesia is one of the cinnamon producing countries. The chemical composition of cinnamon plants varies according to the variety, the part of the plant, the place and the climate to grow. The main bioactive component in cinnamon bark is cynnamaldehide. Cynnamaldehide in cinnamon has good physiological effects on body health such as antioxidants, anticancer, anti-inflammatory, antidiabetic, antidyslipidemic anti-hyperuricemia, and antimicrobial properties. Research is generally still conducted in vitro, clinical trial limited.
\end{abstract}

Keywords - cinnamon; antioxidant; anticancer; cynnamaldehyde.

\section{INTRODUCTION}

Cinnamon is a spice that it has been known for a long time. It has been widely used as a spice in food and medicine. Cinnamon belongs to the family Lauraceae and genus Cinnamomum. The genus Cinnamomum has approximately 250 species, many of which grow in the Asian region. Indonesia is one of the cinnamon producing countries. Cinnamomum burmanii the mostly was planted. The production centers are Jambi and West Sumatra Other types widely traded are C. zeylanicum from South India, Sri Lanka and Madagascar, C. cassia from South China, Myanmar, and Vietnam, C. loureirii from Vietnam, Cambodia and Laos, and C. syntoms from Malaysia [1] and C. osmophoeum from Taiwan [2].

Part of the cinnamon plant traded for a long time was cinnamon bark. Cinnamon bark is processed into many essential oils which are then applied for various purposes such as flavor, cosmetics and medicine. The main component of cinnamon bark is cynnamaldehide [3]. FEMA sets GRAS status for cinnamaldehyde as flavor ingredient [4]. Apart from the actual skin of other parts of cinnamon, leaves and roots also contain many active components that function for health.

\section{THE CHEMICAL COMPOSITION OF CINNAMON}

The main bioactive component in cinnamon bark is cynnamaldehide, but there are also types of cinnamon whose main component is not cynnamaldehyde. Cynnamaldehyde in plants is in the pathic sikimat acid which functions to form lignin. Cynnamaldehide is formed from phenyl alanine through cinnamic acid, and subsequently turns into cynnamil alcohol in the process of lignin formation [3].

The chemical composition of cinnamon plants varies according to the variety, the part of the plant, the place and the climate to grow. The amount and type of compounds identified in the essential oils of the 5 types of cinnamon leaves were different depending on the variety. Consequently the amount of compounds in the essential oils of leaves of C. cassia, C. zeylanicum, C. pauciflorum, $C$. tamala, and $C$. burmannii are 22, 22, 21, 13, and 6. The main volatile components in $C$. cassia leaves aretranscynnamaldehyde $(30.36 \%)$, 3-Methoxy, 1-2, propanediol (29.30\%), and o-Methoxhy cynnamaldehyde (25.39\%), C. zeylaicum are eugenol $(79.75 \%)$ and trans- cynnamaldehide (16.25\%), C. pauciflorum are eugenol (54.74\%), 5-(2Propenyl),1-3, benzodioxole $(17.23 \%)$ and transcynnamaldehide $(12.80 \%)$, C. tamala are 5-(2-Propenyl),13,benzodioxole $(28.67 \%)$ dan trans-cynnamaldehide $(15.90 \%)$, dan $C$. burmanii adalah trans- cynnamaldehide $(60.17 \%)$ dan eugenol (17.62\%) [4]. Cinnamon leaves has phenolic and flavonoid content [5]. The yield of cinnamon oil is influenced by the type of variety. The highest yields of cinnamon leaf essential oils from highest to lowest were $C$. cassia (1.54\%), C. zeylanicum (1.50\%), C. pauciflorum (1.36\%), C. burmannii $(0.78 \%)$. and C. tamala (0.72\%) [4]. Toxicity tests show that trans-cinnamaldehyde does not damage cells [2].

The main components of essential oils from cinnamon bark are cinnamal dehyde $(76.34 \%), 2$ propenal, 3-2-methoxyphenyl (11.02\%) and propanone 1-4methoxyphenyl [6]. The plant age affects the yield of cinnamon bark essential oil. High yields are produced in cinnamon plants that are harvested with more than 12 years of age. The yield and composition of cinnamon bark essential oils on the top, middle and bottom in plants of the same age are different. The highest yield was generated at the top $(2.61 \%)$ followed by the middle $(2.10 \%)$ and bottom $(2.06 \%)$. Extraction of the upper and middle bark are more beneficial than extracting all the components of the bark [7]. 


\section{ANTIOXIDANT ACTIVIY OF CINNAMON}

Cinnamon plants have been known as plants whic contain antioxidants. Antioxidant components are found in leaves, bark, roots and fruit. Different varieties and climate will cause differences in the antioxidant activity. Ethanol extracts from 5 types of cinnamon leaves that grow in China, namely $C$. burmanii, C. cassia, C. pauci fl orum, C. tamala, and $C$. zeylanicum have different antioxidant activities. $C$. zeylanicum leaf extract has the highest DPPH radical scavenging and total antioxidant activity, while $C$. tamala has the highest superoxide anion scavenging activity [5].

Cynnamaldehide Indian bark $C$. verum and $C$. burmanii from Indonesia have antioxidant abilities [3]. Cynnamaldehide is able to suppress DPPH radicals, chelate metals and inhibit peroxidase activity [8]. The active component of butanol fraction from $C$. osmophloeum bark from Taiwan is kaempferol-7-O-rhamnoside. Its antioxidant activity has an $\mathrm{EC}_{50}$ value of $26 \mu \mathrm{M}$ with the DPPH method and $68.1 \mu \mathrm{M}$ with the superoxide scavenger method. This result is better when compared with cathecin which has an $\mathrm{EC}_{50}$ value of $20 \mu \mathrm{g} / \mathrm{ml}$. The butanol fraction has an $\mathrm{EC}_{50}$ of $5 \mu \mathrm{g} / \mathrm{ml}$, it is better than the active component [9].

\section{ANTIDIABETES ACTIVIY OF CINNAMON}

Water extract of $C$. tamala leaves (CTE) from India has the ability as an antidiabetic. The active components in C. tamala leaves are phenol $(20.83 \mathrm{mg} / \mathrm{g} \mathrm{db})$, ascorbate $(22.30 \mathrm{mg} / \mathrm{g} \mathrm{db})$, and caratenoid $(0.82 \mathrm{mg} / \mathrm{g} \mathrm{db})$. Research on mice showed that after taking CTE at a dose of $250 \mathrm{mg} /$ $\mathrm{kg} /$ day for 20 days, the level of sugar in the blood of mice changed from $375 \mathrm{mg} / \mathrm{dL}$ to $75 \mathrm{mg} / \mathrm{dL}$ (normal). The content of gluthatione in the liver increases from $25.66 \mathrm{mM} /$ $100 \mathrm{~g}$ to $45.00 \mathrm{mM} / 100 \mathrm{~g}$ (normal). Next, the contennt of glycogen $\mathrm{t}$ increases from $21.18 \mathrm{mg} / 100 \mathrm{~g}$ to $44.05 \mathrm{mg} / 100$ $\mathrm{g}$, normal mice have glycogen $40.65 \mathrm{mg} / 100 \mathrm{~g}$. CTE reduced Thiobarbituric Acid Reactive Sub-Stances (TBARS) content in the liver of diabetic rats from $1.84 \mathrm{mM} / 100 \mathrm{~g}$ to $1.01 \mathrm{mM} / 100 \mathrm{~g}$, normal rat TBARS was $0.82 \mathrm{mM} / 100$ [10].

Consumption of foods containing $C$. zeylanicum oil $5 \%$ reduced glucose levels in the blood of streptozotocininduced mice from 354.82 to $182.00 \mathrm{mg} / \mathrm{dl}$, triglycerides from 152.04 to $128.16 \mathrm{mg} / \mathrm{dl}$, cholesterol from 102.36 to $76.34 \mathrm{mg} / \mathrm{dl}$ and LDL from $52.72 \pm 1.0$ to $32.95 \mathrm{mg} / \mathrm{dl}$. The essential oil of $C$. zeylanicum decreased AST (alanine aminotransferase) from 119.3 to $84.2 \mathrm{U} / \mathrm{L}$ and decreased ALT (alanine aminotransferase) from 88.8 to $54.8 \mathrm{U} / \mathrm{L}$. AST and ALT activity in blood is increased in diabetic mice. The main compounds in $C$. zeylanicum oil are cinnamaldehyde $62.7 \%, \beta$-caryophyllene $6.5 \%$, eugenol $5.25 \%, \alpha$-terpineol $2.8 \%$ and cinnamyl alcohol $0.18 \%$ [11].

The research showed consumption of $C$. cassia bark powder in people with type II diabetes can reduce blood sugar content. The study was conducted on 60 people with diabetes II from Pakistan (30 men and 30 women), age of 52.2 years and had suffered diabetic for 6.73 years. The results showed consumption of $1,3,6 \mathrm{~g}$ per day for 40 consecutive days reduced blood glucose levels in patients with a range that was not much different, namely $18-29 \%$. Consumption of $1 \mathrm{~g} /$ day of C. cassia powder for 40 days, the patient's sugar levels dropped from 11.6 to $8.7 \mathrm{mmol} / \mathrm{L}$ on day 40 and $9.7 \mathrm{mmol} / \mathrm{L}$ on day 60 (20 days after consuming). In addition cinnamon powder also reduces cholesterol levels in the blood of diabetics by $13-26 \%$, triglycerides $23-30 \%$ and LDL $10-24 \%$. The decrease was still significant after 20 days consuming $C$. cassia (Khan et al., 2003). Consumption of cassia powder in patients with type II diabetes for 40 days at a dose of 4 times $2 \mathrm{~g} /$ day (after breakfast, lunch, afternoon and evening) blood sugar levels in patients dropped from $187.66 \mathrm{mg} / \mathrm{dl}$ (day 0) to $172.93 \mathrm{mg} / \mathrm{dl}$. Addition of $C$. verum water extract to bioyogurts increases the total phenol content and antioxidant activity. Inhibiting the activity of $\alpha$-amylase and $\alpha$ glucosidase enzymes during storage at $4{ }^{\circ} \mathrm{C}$ for 21 days.It is suitable for diabetics drinks [12].

\section{ANTICANCER ACTIVIY OF CINNAMON}

Water extract from cinnamon bark C. cassia has been tested for its ability to inhibit cervical cancer cells in vitro. Extracts $(80 \mu \mathrm{g} / \mathrm{ml})$ can reduce the growth of cancer cells up to three times. Giving the extract causes reduced cancer cell migration, due to the downregulation of MMP-2 expression. Increased cervical cancer cells are comparable to over-expression of Her-2 oncoprotein. Cinnamon extract significantly decreases the expression of Her-2 oncoprotein. In addition, the extract also induces apoptosis in cervical cancer cells through increased intracellular calcium signaling and loss of mitochondrial membrane potential (Koppikar, $2010)$. Lignant ester compound ( $\left(7^{\prime} \mathrm{S}, 8^{\prime} \mathrm{R}, 8 \mathrm{R}\right)$-lyoniresinol9,9'-di-O- (E) -feruloyl ester) was isolated from the stem and roots of $C$. osmophloeum namely. It can suppress cancer cells liver in humans, namely HepG2 (human hepatoma cell line) and Hep3B (human hepatocellular carcinoma) and oral cancer cells $\mathrm{Ca} 9-22$ (gingival cancer) with $\mathrm{IC}_{50}$ values 7.87 , 4.31, and $2.51 \mu \mathrm{g} / \mathrm{mL}[13]$.

One of mechanism of cinnamon leaves as an anticancer through apoptosis. Apoptosis plays an important role in the development of multicellular organisms, regulating and maintaining the balance of cell populations in tissue. Apoptosis induction shows that these compounds can function to prevent the development of cancer. Apoptotic cells are characterized by a shrinking cell nucleus [14].

Cynnamaldehyde can induce apoptosis. Giving cynnamaldehide from $C$. osmophloeum leaves can induce apoptosis of K562 cells (leukemia cells) with concentrations up to $200 \mu \mathrm{M}$. Cynnamaldehyde dehyde induces cell death by altering core morphology, DNA fragmentation, and changing cell morphology (plasma membrane blebbing and cell shrinking). Cynnamaldehyde causes potential loss of mitochondrial transmembrane, stimulates the production of reactive oxygen species (ROS), releases mitochondrial cytochrome into cytosol and subsequently induces procaspase- 9 and procaspase- 3 processes. Increasing ROS 
and decreasing glutathione are suspected cynnamaldehyde mechanisms in inducing K526 cells [15].

\section{ANTI-INFLAMMATORY OF CINNAMON}

Cinnamon is used as an anti-inflammatory and has an effect on nitric oxide (NO), nuclear factor kappa-b (NF$\mathrm{kB}$ ) and PGE2. NO is a free radical synthesized from Larginine by nitric oxide synthase (NOS) in mammalian cells or tissues. NO are needed to regulate physical homeostasis, but large increases in NO are associated with various diseases and inflammation. NO production is related to the accumulation of PGE2 which will affect pathogenesis. NF$\kappa \mathrm{B}$ induces inflammation through induction of transcriptional code for inflammatory mediator genes. Cynnamaldehyde in $C$. cassia extract inhibits inflammation by inhibiting NO production and NF-kB transcription activity [16].

Trans-cinnamaldehyde from C. osmophloeum twig essential oil from Taiwan has the ability to suppress NO synthase ( $\left.\mathrm{IC}_{50} 88.4 \mu \mathrm{M}\right)$. Giving trans-cinnamaldehyde 10 $\mu \mathrm{g} / \mathrm{ml}$ can inhibit NO 59.9\%. Whereas using essential oils from C. osmophloeum twig at a concentration of $10 \mu \mathrm{g} / \mathrm{ml}$ NO production can be inhibited by $48.3 \%$. This result is lower than that of curcumin as a comparison, where curcumin $10 \mu \mathrm{g} / \mathrm{ml}$ inhibits NO about $80 \%$. The administration of C. osmophloeum $10 \mu \mathrm{g} / \mathrm{ml}$ essential oil can inhibit the accumulation of PGE2 in $65 \%$ cells, this result is lower when compared with indomethacin (commercial drugs) which is $98 \%$. Other components of $C$. osmophloeum essential oil can suppress NO. At a concentration of $10 \mu \mathrm{g} / \mathrm{ml}$ caryophyllene inhibits $\mathrm{NO}$ by $54.0 \%$, L-borneol $46.1 \%$, L-bornyl acetate $45.7 \%$, eugenol $46.2 \%$, b-caryophyllene $40.9 \%$, E-nerolidol $407 \%$, aterpineol $38.1 \%$ and p-allylanisole $30.9 \%$ lower than MCO [2].

As an anti-inflammatory cynnamaldehyde can inhibit the secretion of interleukin-1beta and tumor necrosis factor alpha in lipopolysaccharides (LPS) or liplipoteicoic acid (LTA) which stimulates murine J774A.1 macrophages. Cynnamaldehide also suppresses the production of cytokines from LPS. Furthermore ROS released from the LPS that stimulates J774A.1 macrophages can be reduced by cynnamaldehyde. Cynnamaldehyde inhibits extracellular posporilation regulated by signal kinase $1 / 2$ and c-Jun Nterminal kinase $1 / 2$ on LPS [17].

\section{ANTIDYSLIPIDEMIC OF CINNAMON}

The active component of $C$. osmophloeum (COE) hot water extract is kaemferol 3-O- $\beta$-D-apiofuranosyl- (1-2) $-\alpha$-L-arabinofuranosyl-7-O- $\alpha$ L-rhamnopyranoside $\quad(7.56 \%)$. Consumption of COE in hamsters with a high fat diet has been shown to reduce the content of total cholesterol (TC), triglycerides (TS) and low density lipoprotein (LDL-C). Consumption of COE $100 \mathrm{mg} / \mathrm{kg}$ for 5 weeks was reduced TC $12.63 \%$ and TG $34.25 \%$. Consumption for 10 weeks decreased TC $33.88 \%$, TG $36.88 \%$. LDL $27.77 \%$, without damage to the hamster's kidneys and liver. The content of glutamate oxaloacetate transaminase (GOT) and glutamic pyruvic transaminase (GPT) in blood does not differ between normal hamsters and those consuming COE (Lin et al. 2011). Consumption of water extract of $C$. tamala leaves from India $400 \mathrm{mg} / \mathrm{kg}$ for 10 days reduced TC $20.01 \%$, TS $19,68 \%$, and LDL-C $28.9 \%$ in high fat diet albino rats [18].

\section{ANTI-HYPERURICEMIA OF CINNAMON}

Cinnamaldehyde from essential oils from C. osmophloeum leaves can reduce uric acid content in the blood. Giving cinnamaldehyde in mice suffering from hyperuricemic at a dose of $150 \mathrm{mg} / \mathrm{kg}$ reduced uric acid rats by $84.48 \%$. Cinnamaldehyde can inhibit the activity of the enzyme xanthine oxidase (XOD) with an IC50 value of 8.4 $\mu \mathrm{g} / \mathrm{ml}$. XOD is an enzyme that catalyzes the oxidation reaction of hypoxanthine and xanthine to gout. Inhibition of XOD activity will inhibit the biosynthesis of gout [19].

\section{ANTIMICROBIAL OF CINNAMON}

The main components essential oils from $C$. cassia leaves from China are cinnamaldehyde (65\%) and methoxycinnamaldehyde (21\%). This essential oil can inhibit the growth of pathogenic bacteria in vitro. The pathogenic bacteria that were inhibited were Escherichia coli O157: H7 with MIC value of $0.05 \%$ and MCT $0.013 \%$, Salmonella typhimurium SL 134 with MIC value of $0.025 \%$ and MCT $0.013 \%$, Staphylococcus aureus with MIC value of $0.025 \%$ and MCT $0.013 \%$, and against Listeria monocytogenes with MIC values $0.05 \%$ and MCT $0.025 \%$. Antimicrobial activity is high if $\mathrm{MIC} \leq 0.01 \%$ and $\mathrm{MTC} \leq 0.025 \%$ [20].

The main components essential oils from $C$. verum leaves from Madagascar are eugenol (63\%) and carryophyllene $(5 \%)$. This essential oil can inhibit the growth of E. coli O157: $\mathrm{H} 7$ with MIC value of $0.1 \%$ and MCT $0.013 \%$, S. typhimurium SL 134 with a MIC value of $0.1 \%$ and MCT $0.013 \%$, S. aureus with a MIC value of $0.05 \%$ and MCT $0.013 \%$, and against L. monocytogenes with MIC values $0.2 \%$, MCT $0.006 \%$ [19]. (Oussalah et al., 2007). Application of $0.3 \%$ cinnamon in pasteurized apple juice can activate the growth of S. typhimurium, Y. and $S$. aureus when stored at 5 and $20^{\circ} \mathrm{C}$ for 20 days [21].

Cinnamon oil $3 \%$ can inhibit the growth of Rhizopus nigricans with MIC value of $0.16 \%$ (Xing et al., 2010). While the essential oil of $C$. jensenianum $8 \mu \mathrm{l} / \mathrm{ml}$ can inhibit $100 \%$ of the process of germination of spores from Aspergilus flavus [22]. (Tian et al., 2011). Essential oils made from cinnamon waste (C. zeylanicum) with main compounds are cynnamaldehide (66.62\%), sinamil acetate (13.89\%), linalool (4.96\%) and $\beta$-caryophilen (4.45\%). This oil can inhibit Colletohricum musa with MIC value $0.86 \mathrm{mg}$ $/ \mathrm{ml}$ and MLC of $1 \mathrm{mg} / \mathrm{ml}$, Fusarium proliferatum with MIC value $0.64 \mathrm{mg} / \mathrm{ml}$ and MLC of $0.86 \mathrm{mg} / \mathrm{ml}$ in vitro. This compound is able as an antimicrobial to extend the shelf life of bananas. Cynnamal dehyde most strongly inhibits growth of fungi [23]. 
The essential oil of $C$. zeylanicum can inhibit the growth of $C$. coccodes, Botrytis cinerea, Cladosporium herbarum, and A. niger at concentrations of 25-500 ppm in vitro [24], A. flavus and , A. ochraceus [25]. C. zeylanicum bark extract can inhibit the growth of Candida albicans and Saccharomyces cerevisiae, the inhibition zone is much greater than the standard antifungal drug amphotericin B [26].

\section{CONCLUSIONS}

The main component of cinnamon is cynnamadehid. This component has many benefits against cardiovascular diseases such as antidiabetic, uric acid, and cancer. Research has been done in vitro and in vivo, while clinical trials are still limited

\section{REFERENCES}

[1] Gowder, S and Devaraj, H. 2010. A Review of the Nephrotoxicity of the Food Flavor Cinnamaldehyde. Current Bioactive Compounds 6:106-117).

[2] Tung, YT., Chua, MT., Wang, SY., dan Chang, ST. 2008. Anti-inflammation activities of essential oil and its constituents from indigenous cinnamon (Cinnamomum osmophloeum) twigs. Bioresource Technology 99. 3908-3913.

[3] Ravindran, PN., Babu, KN and Shilaja, N. 2004. Cinnamon and Cassia Genus Cinnamomum. CRC Press. Washington DC.

[4] Wang, R., Wang, R and Yang, B. 2009. Extraction of essential oils from five cinnamon leaves and identification of their volatile compound compositions. Innovative Food Science and Emerging Technologies 10:289-292.

[5] Prasad, KN., Yang,B., Dong, X., Jiang, G., Zhang, H., Xie.H, dan Jiang, Y. 2009. Flavonoid contents and antioxidant activities from Cinnamomum species. Innovative Food Science and Emerging Technologies 10:627-632.

[6] Xing, Xihong L, Qinglian X, Juan Y and Yaqing L. 2010. Antifungal activities of cinnamon oil against rhizopus nigricans, aspergillus flavus and penicillium expansum in vitro and in vivo fruit test. International Journal of Food Science and Technology 45: 18371842.

[8] Mathew, S dan Abraham, TE. 2004. Studies on the antioxidant activities of cinnamon (Cinnamomum verum) bark extracts, through various in vitro models. Food Chemistry 94:520-528.

[9] Chua, MT., Tung, YT., dan Chang, ST. 2008. Antioxidant activities of ethanolic extracts from the twigs of Cinnamomum osmophloeum. Bioresource Technology 99:1918-1925.

[10] Chakraborty, U and Das, H. 2010. Antidiabetic and Antioxidant Activities of Cinnamomum tamala Leaf
Extracts in Stz-Treated Diabetic Rats. Global Journal of Biotechnology \& Biochemistry 5 (1):12-18.

[11] Allogmani, A dan Zari, TA. 2009. Effects of Nigella sativa L. and Cinnamomum zeylanicum Blume oils on some physiological parameters in streptozotocininduced diabetic rats. Boletín Latinoamericano y del Caribe de Plantas Medicinales y Aromáticas, 8 (2): 86 $-96$.

[12] Shori, AB and Baba, AS. 2011. Cinnamomum verum improved the functional propertiesof bioyogurts made from camel and cow milks. Journal of the Saudi Society of Agricultural Sciences 10: 101-107.

[13] Chen, TH., Huang, YH., Lin, JJ., Liau, BC., Wang, SY., Wu, YC., dan Jong, TT. 2006. Cytotoxic lignan esters from Cinnamomum osmophloeum. Original Paper. Planta Med.

[14] Purwani, EY. 2011. Penghambatan Proliferasi Sel Kanker Kolon HCT-116 oleh Produk Fermentasi Pati resisten Tipe 3 Sagu dan Beras. Bahan Ujian Terbuka Program Doktor Ilmu Pangan IPB.

[15] Huang, TC., Fu, HY., Ho, CT., Tan, D, Huang, YT., dan Pan, MH. 2007. Induction of apoptosis by cinnamaldehyde from indigenous cinnamon Cinnamomum osmophloeum Kaneh through reactive oxygen species production, glutathione depletion, and caspase activation in human leukemia K562 cells. Food Chemistry 103:434-443.

[16] Maxwell, AE dan Tran ,T. 2007. Cinnamon more than just a flavoring agent. US Pharm 32(12):38-42.

[17] Chao., LK., Hua, KF., Hsu, HY., Cheng, SS, Lin, IF, Chen, CJ., Chen, ST., and Chang, ST. 2007. Cinnamaldehyde inhibits pro-inflammatory cytokines secretion from monocytes/macrophages through suppression of intracellular signaling. Food and Chemical Toxicology 46:220-231

[18] Dhulasavant, V., Shinde, S., Pawar, M dan Naikwade, NS. 2011. Antihyperlipidemic activity of Cinnamomum tamala Nees. on high cholesterol diet induced hyperlipidemia. Int. J. of Pharm. \& Life Sci. 2(1): 506510.

[19] Wang, SY., Yanga, CW., Liaob, JW, Zhena, WW., Chuc, FH., and Chang, ST. 2008. Essential oil from leaves of Cinnamomum osmophloeum acts as a xanthine oxidase inhibitor and reduces the serum uric acid levels in oxonate-induced mice. Phytomedicine 15:940-945.

[20] Oussalah, M., Caillet, S., Saucier, L., and Lacroix, M. 2007. Inhibitory effects of selected plant essential oils on the growth of four pathogenic bacteria: E. coli O157:H7, Salmonella Typhimurium, Staphylococcus aureus and Listeria monocytogenes. Food Control 18 (2007) 414-420.

[21] Yuste, J and Fung, DYC. Evaluation of Salmonella typhimurium, Yersinia enterocolitica and Staphylococcus aureus counts in apple juice with cinnamon,by conventional media and thin agar layer method. Food Microbiology 20:365-370. 
[22] Tian, J, Bo H, Xiuli L, Hong Z, Xiaoquan B, Jingsheng H, and Youwei W. 2011. The control of Aspergillus flavus with Cinnamomum jensenianum Hand.-Mazz essential oil and its potential use as a food preservative. Food Chemistry 130 (2012) 520-527.

[23] Ranasinghe, L, Bimali, J and Krisshanti A. 2003. Use of waste generated from cinnamon bark oil extraction as postharvest treatment for embul banana. Food Agriculturr \& Environment. 1 (2): 340-344.

[24] Tzortzakis, NG. 2009. Impact of cinnamon oilenrichment on microbial spoilage of fresh produce. Innovative Food Science and Emerging Technologies 10: $97-102$.
[25] Singh, G., Maurya, S., Lampasona, MP and Catalan CAN. 2007. A comparison of chemical, antioxidant and antimicrobial studies of cinnamon leaf and bark volatile oils, oleoresins and their constituents. Food and Chemical Toxicology 45:1650-166.

[26] Aneja, KR., Joshi, R and Sharma, C. 2009. Antimicrobial activity of Dalchini (Cinnamomum zeylanicum bark) extracts on some dental caries pathogens. Journal of Pharmacy Research 2(9):13871390. 